\title{
DEMAND FOR COMPETENCES OF INDUSTRIAL ENGINEERING GRADUATES IN THE CONTEXT OF AUTOMATION OF MANUFACTURING PROCESSES
}

doi: 10.2478/cqpi-2019-0026

Date of submission of the article to the Editor: 06/04/2019

Date of acceptance of the article by the Editor: 19/05/2019

Wojciech Gliń ${ }^{1}$ - orcid id: 0000-0002-8295-5702

Tomasz Nitkiewicz ${ }^{1}$ - orcid id: 0000-0003-2983-9195

Wichai Chattinnawat ${ }^{2}$ - orcid id: 0000-0003-1936-9919

${ }^{1}$ Czestochowa University of Technology, Poland

${ }^{2}$ Chiang Mai University, Thailand

Abstract: Automation and robotization is considered to be a key determinant of the development and innovation in manufacturing enterprises. But the scope and range of its implementation is changing due to ongoing fourth industrial revolution towards Industry 4.0. The objective of the paper is to analyze the needs of manufacturing enterprises with regard to automation and robotization but from the perspective of desired competences of Industrial Engineering graduates. To achieve the objective the results of industrial survey are analyzed. The survey was made among Thai and EU companies within the project titled Curriculum Development of Master's Degree Program in Industrial Engineering for Thailand Sustainable Smart Industry -MSIE4.0. The results show that the requirements towards graduates are changing especially with reference to real-time control of manufacturing process, big data use and mobile devices use to steer and feed with the information the management and manufacturing processes.

Keywords: industrial engineering, automation and robotization, demand for competences in industrial engineering, quality of education

\section{INTRODUCTION}

The fourth industrial revolution (Industry 4.0) is a concept referring to the changes that take place in industrial activity due to the currently observed systemic use of information technologies through the development of automation, data processing and data exchange, manufacturing techniques and management organization of all processes. Definitionally, the fourth industrial revolution is a term for the description of technology and the principles of functioning of business organizations that systematically apply:

a) cyberphysical systems and modeling,

b) Internet of things and services,

c) cloud processing capabilities.

d) The Internet of Things (Bendkowski, 2017) 
Taking into account the above-mentioned phenomena, it can be concluded that the fourth industrial revolution is "the realization of an intelligent factory in which cyberphysical systems control physical processes, create virtual copies of the real world and make decentralized decisions. Through real-time Internet, they communicate and cooperate with each other and with people, while cloud computing offers internal and inter-operable services. " (Hermann et al., 2016)

The current revolution is a breakthrough change in the production of goods. It is caused by:

- introduction of ubiquitous digitization, which is reflected in the ubiquity of information technologies in every area of life,

- basing in decision processes on virtual simulations and real-time data processing,

- changes in the machine-machine communication and machine-man communication strategy (Internet of Things),

- dissemination of new manufacturing technologies, including flexible production lines. (Furmanek, 2018)

Along with the already mentioned Internet of Things and Services and cyber-physical systems, key components of Industry 4.0 are also: intelligent factories, Big Data and horizontal and vertical integration of the system.

In view of the rapid development of new systems of the functioning of industry, there is a clear need to adjust the competencies of employees to the specificity of this development (Hariharasudan \& Kot, 2018, Ślusarczyk, 2018, Nitkiewicz et al., 2019). The issue of competences is of interest to various scientific disciplines and research trends. The subject of competence is taken up by such sciences as: - law - emphasizes the formal aspect, competence is identified with power of attorney, - sociology emphasizes the aspect of shaping the relations of consciousness of various social groups; competence is the ability to behave in a manner consistent with culturally shaped patterns; - psychology - competence as ability, ability to do something correctly or effectively; it is also the scope of the ability or knowledge of a given person or group, - praxeology - competences as characteristics of the subject of action relativized to the smooth performance of a specific act, fulfillment of functions in the organization, management - competence as the ability to effectively, effectively and ethically manage. (Stabryła, 2011)

Undoubtedly, the basic components of competence are knowledge and skills. Knowledge includes everything an employee has learned both during the formal education process and as part of self-education. Skills are related to both the process of education and self-study as well as professional practice.

The higher education system plays a very important role in shaping the competencies of future employees. Universities, in order to fulfill their mission, must "think" in a longterm and construct their education programs in order to meet the changing socioeconomic conditions, including to prepare the economy for the development of Industry 4.0. This is particularly important in relation to technical universities, and in particular their fields of study in the field of Industrial Engineering (IE).

In education in these fields, it is particularly important to combine knowledge with practice and keep up with the ongoing changes in industry (Nitkiewicz \& Ayen, 2018). Engineers are expected to have creative, creative thinking skills and to link knowledge with practice. The development of competencies is necessary for effective functioning 
in professional life and especially in response to dynamic changes in processes and applied technologies (Lima et al., 2017, Prifti et al., 2017).

\section{SCOPE OF RESEARCH}

Project Curriculum Development of the Master's Degree Program in Industrial Sustainable Smart Industry - MSIE4.0 (hereinafter referred to as "MSIE4.0 Project") is a project of 9 colleges, 3 from the EU and 9 from Thailand, implemented as part of Erasmus + program 2. The goal of the MSIE4.0 project is to increase the potential and opportunities of universities in Thailand to experience high-quality curriculum - based on competences, as part of the master's program in Production Engineering, industrial, which supports sustainable intelligent industry and is in line with the European Qualifications Framework (EQF)

As part of the MSIE4.0 Project, questionnaire surveys were carried out among enterprises and among students and graduates of IE faculties. Answers were collected from 72 enterprises (50 companies from Thailand and 22 companies from EU partner countries) and 450 students, which allowed to identify competences that are perceived as key in the field of Production Engineering from the perspective of Industry 4.0. The design of the study allows for comparative assessment or competences according to the needs of students are tailored to the needs of the industry.

The analysis concerned competences that were based on a comparison of the current state of competence development in the area of IE, and the assessment of own competences by students from the IE area and industry needs, which must develop towards Industry 4.0. The article focuses on a selected area of enterprise operation, ie automation and robotics, which on the one hand is one of the areas undergoing the greatest changes in the transition from the third to the fourth industrial revolution.

\section{RESEARCH RESULTS AND DISCUSSION}

The general analysis of the results is presented in the framework of the MSIE4.0 Project documentation (https://msie4.ait.ac.th/), therefore the article focuses only on issues related to automation and robotization. Figure 1 shows the ability to define / implement the concept of Industry 4.0. The majority of respondents answered that they are not able to identify and implement strategies Industry 4.0, which shows that it is not that the education in the fields of IE is not yet adapted to the requirements of the fourth industrial revolution.

About $70 \%$ of respondents perceive themselves as people who have no competence to define and implement the concept of Industry 4.0, but are aware that competencies should be developed in the past or should be developed over the next year. 


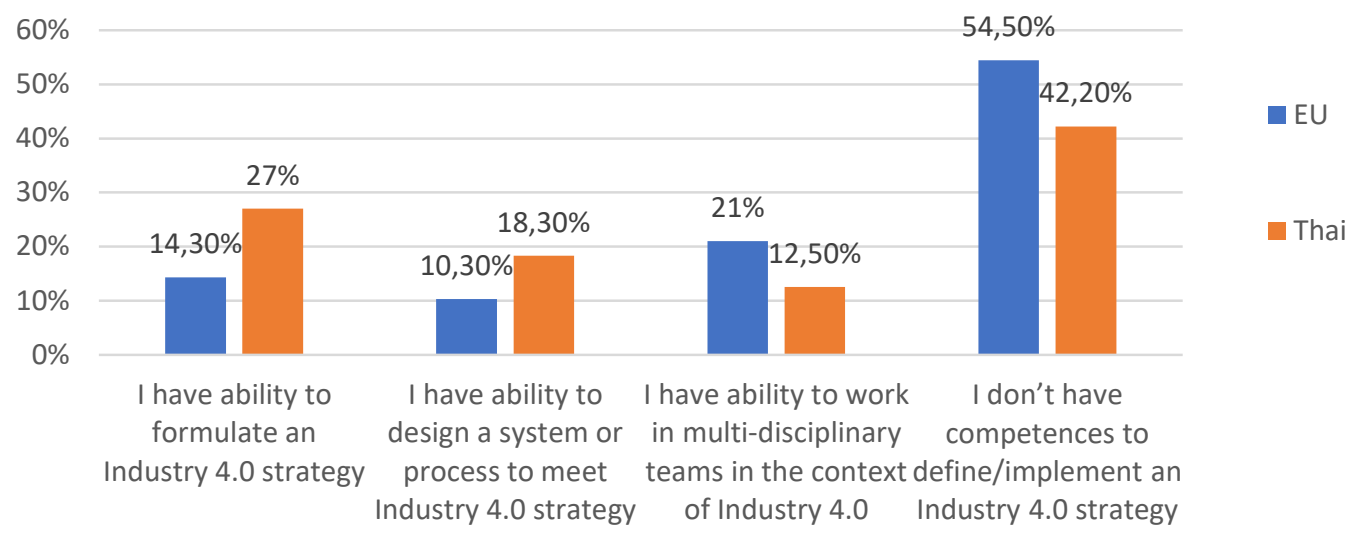

Fig. 1. Students' description of their ability to define/implement Industry 4.0 strategies Source: ERASMUS+ CBHE PROJECT, Curriculum Development of Master's Degree Program in Industrial Engineering for Thailand Sustainable Smart Industry, WP 1 - Gap Analysis, Outcome 1.4 Analysis of needs of industry and students

Students were questioned about the perception of their own level of understanding of specific technologies regarding Industry 4.0. As shown in Figure 2, the majority of students indicate that they have no knowledge or competence regarding these technologies. This is particularly visible for the competences associated with automation and robotization, such as M2M communication, integrated IT systems or the use of sensors to control the course of production processes. The colors in Figure 2 symbolize the connection of areas with automation and robotization.

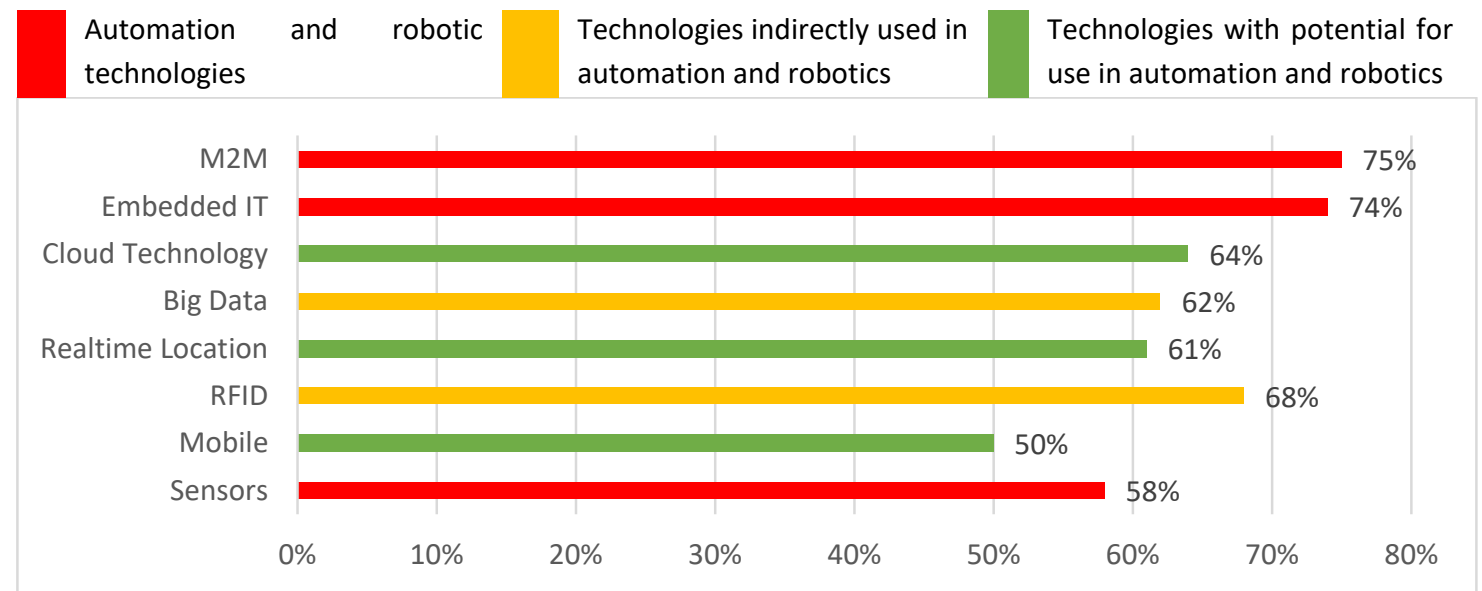

Fig. 2. Percentage of students without knowledge or competence regarding specific technologies

Source: ERASMUS+ CBHE PROJECT, Curriculum Development of Master's Degree Program in Industrial Engineering for Thailand Sustainable Smart Industry, WP 1 - Gap Analysis, Outcome 1.4 Analysis of needs of industry and students

Figure 3 shows the results on the same question in relation to businesses, indicating which technical skills are needed for an employee to improved economic activity. We can say that the results show the most important area from the perspective of the implementation of the industry 4.0 technology and necessary competencies in this context. 
Technologies strongly associated with automation and robotization, there is diversity in this context. Sensor technologies, together with Big Data technologies, are the most important development directions at present, however, for sensors there is no such a strong gap between the used and required level of advancement as for Big Data technology. Technologies of integrated IT systems are significantly less desirable, but they are developed to a degree very similar to expected. The expectations regarding the M2M communication technology are relatively the smallest, but there is the biggest gap.

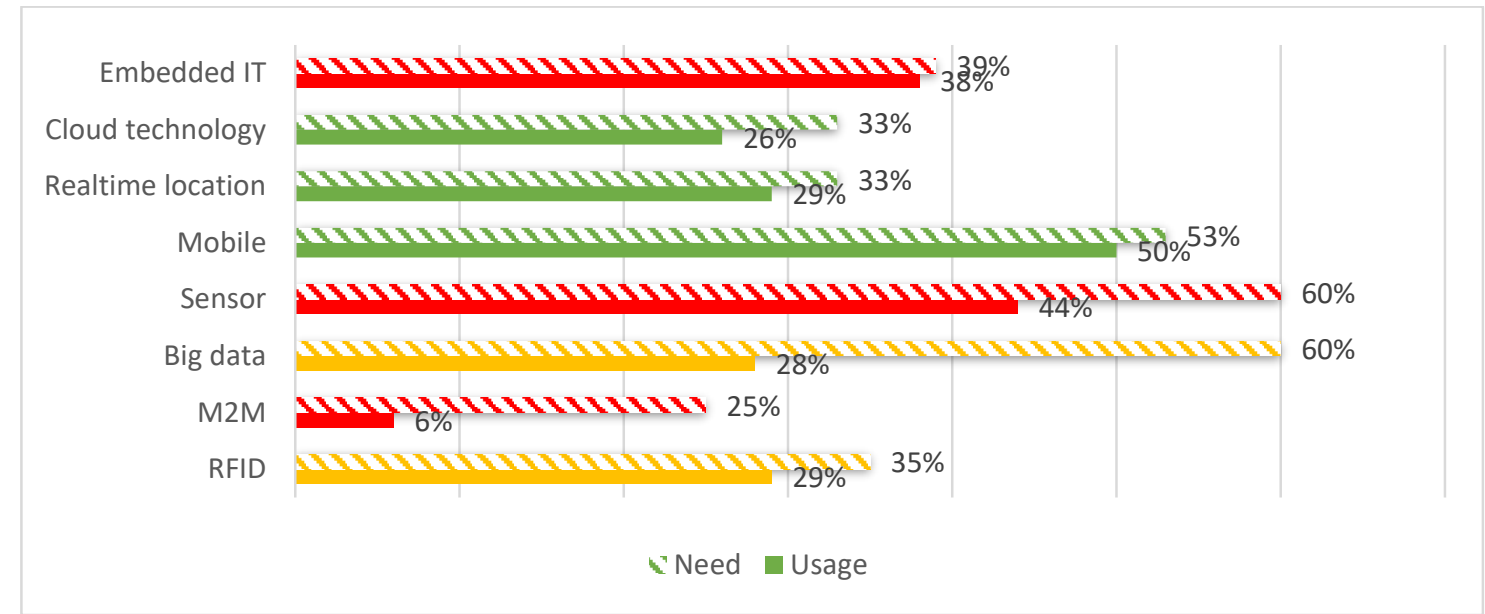

Fig. 3 Technological competence needed for employee to enhance business operation Source: ERASMUS+ CBHE PROJECT, Curriculum Development of Master's Degree Program in Industrial Engineering for Thailand Sustainable Smart Industry, WP 1 - Gap Analysis, Outcome 1.4 Analysis of needs of industry and students

One of the questions addressed to enterprises was whether they have production processes that react automatically in real time to changes occurring in production conditions. Fig 4. presents the current status of autonomy of workpieces and production processes in interviewed companies. As could be observed, the majority of the companies have no such a systems or have them just in pilot or limited areas.

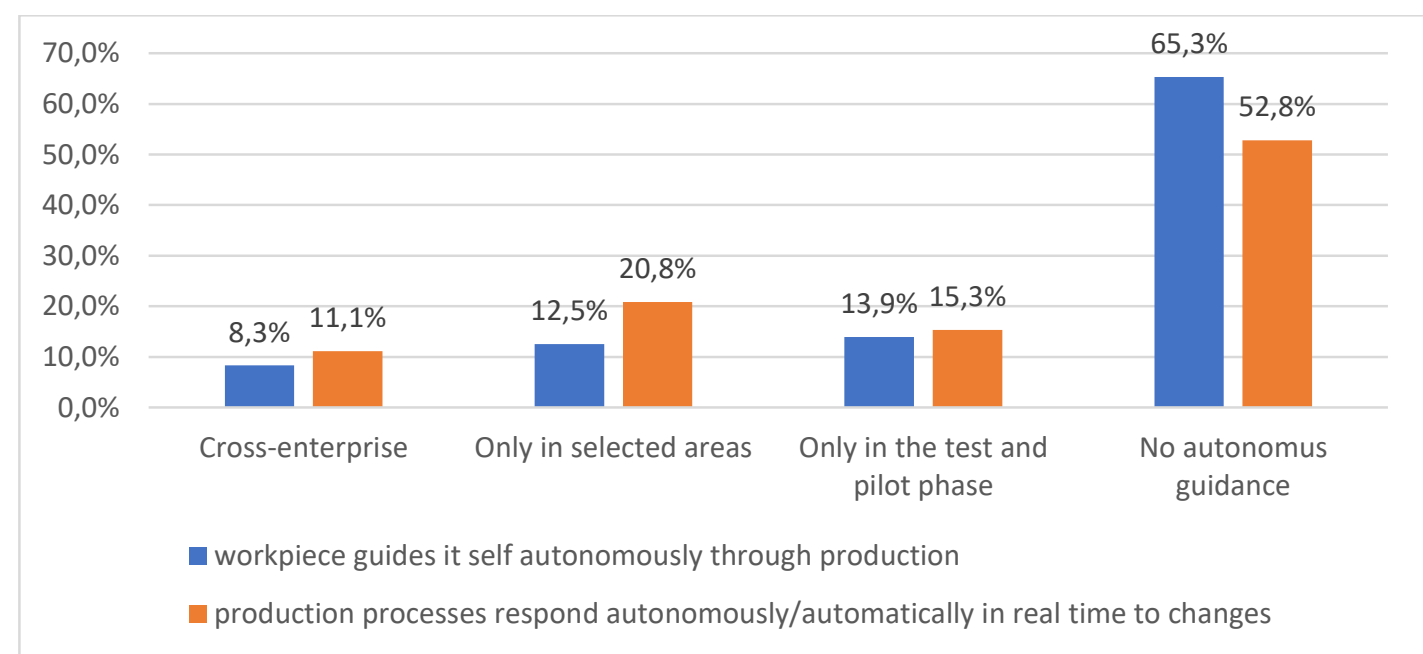

Fig. 4. Autonomous guidance of workpieces and responds of production processes Source: ERASMUS+ CBHE PROJECT, Curriculum Development of Master's Degree Program in Industrial Engineering for Thailand Sustainable Smart Industry, WP 1 - Gap Analysis, Outcome 1.4 Analysis of needs of industry and students 
It seems that the competences are needed in the filed of adopting existing and possible automatization and robotization efforts towards self-guiding and autonomous systems. The role of IE graduates should focus perhaps not on the hardware and technology but rather on organizational efforts, aiming at integrating the potential into the synergic, Industry 4.0 ready manufacturing system. The problem is that currently such competences are not acquired through IE first and second level of higher education but could be gather through combined studies on ICT, robotics, management and different engineering studies. Steering MSc of IE towards the abovementioned competences would mean development of more holistic and technology \& engineering \& transversal competences integrating program. It would certainly be a big change within curriculum and would probably not go without significant costs. These costs would be mainly related to dropping out many industry related skills that are not more feasible with Industry 4.0 but still often used and needed.

\section{CONCLUSIONS}

The project was to assess the situation regarding studies in the area of Industrial Engineering offered in Thailand and EU partner countries and to identify gaps between actual and current needs of students, businesses.

The results in the pedagogical approach have shown that there is a lack of active environments and teaching methods that could contribute to the development of competences towards Industry 4.0. Moreover, these environments could be developed through interdisciplinary learning of problems and projects in interaction with the associated industries, which would contribute to the emergence of more flexible and tailor-made study programs.

From the results obtained, the main needs of enterprises regarding the development towards Industry 4.0 were determined, such as: Big Data, mobile devices and sensors. These results were confirmed in the questionnaire by students and showed that the respondents perceive the need to develop these technologies and competences associated with them.

A team of experts participating in the project has developed a perspective on the current level of competence development that was deemed necessary for students to provide support to enterprises towards Industry 4.0. The current level of competence has been proposed by a team of experts involved in the project, influenced by the collected information needed to analyze study programs. Finally, a comparison of the current level of competence development and the necessary competences allowed to identify a gap in students' competences.

General conclusions should indicate the key issues that are spotted with regard to automation processes and their role in fourth industrial revolution, both from the perspective of industry and its future workforce. It seems that the expectations are quite high, especially concerning rather low skills of IE graduates concerning Industry 4.0 strategic approach and its specific technologies. On the other hand, industry is quite specific concerning its expectations and competences needed with regard to its current gap between current and desired status of its technological advancement to attain Industry 4.0. The role of universities, certainly within the field of IE types of studies, should be to bridge this gap between the two. It could be only achieved through revolutionary changes not only in content of $\mathrm{MSc}$ of IE programs but also within educational approach used. 


\title{
ACKNOWLEDGEMENTS
}

This publication is a partial outcome of project "Curriculum Development of Master's Degree Program in Industrial Engineering for Thailand Sustainable Smart Industry (MSIE4.0)" that has been funded with support from the European Commission (Project Number: 586137-EPP-1-2017-1-TH-EPPKA2-CBHE-JP). This publication reflects the views only of the authors, and the Commission cannot be held responsible for any use which may be made of the information contained therein.

\author{
Co-funded by the \\ Erasmus+ Programme \\ of the European Union

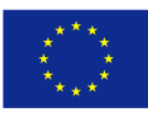

\section{REFERENCES}

Bendkowski J., 2017. The impact of industry 4.0 on production work, Zeszyty Naukowe. Organizacja i Zarządzanie / Politechnika Śląska, z. 112, 21-33

BMBF, 2014. The new High-Tech Strategy Innovations for Germany. https://www.fona.de/pdf/publikationen/bmbf_the_high_tech_strategy_for_germany. pdf

Boyatzis R.E., 1982, The Competent Manager: A Mode for Effective Performance, New York: Wiley

ERASMUS+ CBHE PROJECT, Curriculum Development of Master's Degree Program in Industrial Engineering for Thailand Sustainable Smart Industry, WP 1 - Gap Analysis, Outcome 1.4 Analysis of needs of industry and students, https://msie4.ait.ac.th/outcome-1-4-analysis-of-needs-of-industry-and-students/

ERASMUS+ CBHE PROJECT, Curriculum Development of Master's Degree Program in Industrial Engineering for Thailand Sustainable Smart Industry, WP 1 - Gap Analysis, Outcome 1.5 - Gaps between the needs and graduates' competences, https://msie4.ait.ac.th/outcome-1-5-gap-analysis/

ERASMUS+ CBHE PROJECT, Curriculum Development of Master's Degree Program in Industrial Engineering for Thailand Sustainable Smart Industry, WP 1 - Gap Analysis, Outcome 1.6 - Competitive factors for the curriculum, https://msie4.ait.ac.th/outcome-1-6-competitive-factors-for-the-curriculum/

Furmanek W., 2018, The most important ideas of the fourth industrial revolution, Dydaktyka informatyki, T. 13, 55-63

Hariharasudan, A., \& Kot, S. (2018). A scoping review on Digital English and Education 4.0 for Industry 4.0. Social Sciences, 7(11), 0-13. http://doi.org/10.3390/socsci7110227

Hermann M., Pantek T., Otto B., 2016. Design Principles for Industrie 4.0 Scenarios, https://www.thiagobranquinho.com/wp-content/uploads/2016/11/Design-Principlesfor-Industrie-4_0-Scenarios.pdf

Lima, R. M., Mesquita, D., Rocha, C., Rabelo, M., Lima, R. M., Mesquita, D., ... Rabelo, M. (2017). Defining the Industrial and Engineering Management Professional Profile: a longitudinal study based on job advertisements. Production, 27(spe). http://doi.org/10.1590/0103-6513.229916

Management of Czestochowa University of Technology., Polish J. Manag. Stud., 8,

Nitkiewicz T., D. Hussadintorn Na Ayutthaya, P. Koomsap, R.M. Lima, W. Chattinnawat, 2019. The Quality of Education on Workplace Safety Master Studies - The Issue of Teaching Methods, System Safety: Human - Technical Facility Environment 1(1), https://doi.org/10.2478/czoto-2019-0084, pp. 661-669 
Nitkiewicz T., Z. Ayen 2018. Identifying key criteria in development of Industrial Engineering education. MATEC Web of Conferences, 183, http://doi.org/10.1051/matecconf/201818304008 pp. 259-268,

Prifti L., M. Knigge, H. Kienegger, H. Krcmar, (2017). A Competency Model for 'Industrie 4.0' Employees, in Proceedings der 13. Internationalen Tagung Wirtschaftsinformatik (WI 2017), pp. 46-60.

Rzempała J., 2017. The individual and organizational competencies in project management - the system approach, Zeszyty Naukowe. Organizacja i Zarządzanie, Politechnika Śląska, z. 114, 417-430

Stabryła A., 2011. Przegląd problemów doskonalenia systemów zarządzania przedsiębiorstwem, Mfiles.pl, seria wydawnicza: Encyklopedia Zarządzania

Ślusarczyk, B. (2018). Industry 4.0 - Are We Ready? Polish Journal of Management Studies, 17(1), 232-248. http://doi.org/10.17512/pjms.2018.17.1.19

Ulewicz R. 2013. System Approach To Assure Quality of Education At the Faculty of Management of Czestochowa University of Technology., Polish J. Manag. Stud., 8, pp. 259-268 